\title{
Sacrifice in Modernity: Community, Ritual, Identity
}

\author{
Joachim Duyndam, Anne-Marie Korte and Marcel Poorthuis
}

Sacrifice, Opfer, Yajna - the various terms for sacrifice that can be found across different religious traditions show the many aspects that are perceived as constituting its core business, such as making holy, gift-giving, exchange, or the loss of something valuable. Since the mid 19th century, scholars studying written or performed sacrificial acts have tried to capture its essence with concepts such as bribery (Edward Burnett Tylor), a gift to the gods (Marcel Mauss), an act of consensual violence (René Girard), or a matter of cooking (Charles Malamoud). The act of offering sacrifices is undoubtedly one of the most universal religious phenomena. From time immemorial, offering a sacrifice has been considered the proper way to approach the godhead. Whether the goods to be offered were products from the harvest, the firstlings of the flock, flowers, or flour, the believers expressed their gratitude, begged for divine favours or tried to appease the godhead or the community. ${ }^{1}$ The transformations - or re-embodiments - of sacrifice that have taken place in many religions have included prayer, almsgiving, fasting, continence, and even martyrdom. These acts not only imply an effort to offer something of value, but often also a form of self-surrender, a surrender to the divine. However, these sacrificial religious practices, as such, seem to have lost most of their relevance and resonance in the context of modern western societies. Secularization and the decline of institutional religion have rendered them obsolete, dissolving the specific contexts and discourses that made these practices self-evident and meaningful.

But is this indeed the case? In this volume, consisting of a collection of studies into contemporary forms and manifestations of sacrifice, or sacrifice-like activities, it is argued that religious phenomena such as sacrifice, even when they have lost their significance as a strictly religious ritual, have persisted in manifold manifestations. Philosophers and sociologists of religion have argued that the classical secularization thesis, which states that religion declines when science makes progress, is no longer tenable for large parts of the modern world. They view, on the one hand, secularization as an intrinsic outcome

1 Catherine Bell, Ritual: Perspectives and Dimensions (New York: Oxford University Press 1997), 112: "Some form of sacrifice can be found in almost all societies." 
of, especially, Christianity, ${ }^{2}$ and point, on the other, to a nascent post-secular condition of western societies. ${ }^{3}$ Without reaching any definitive conclusions about these tendencies, the studies that follow explore the centrality of rituals of sacrifice in a variety of areas, such as politics, daily and communal life, ethics, art, and popular culture. Indeed, the subtitle of this book has been aptly chosen: among the cases that will be covered are the Harry Potter book series, the movies of the Twilight Saga, and present day self-sacrificing caregiving. Without a doubt, many of these examples draw upon centuries old sacrificial patterns and images and can only be understood in combination with a thorough knowledge of sacrifice in all its ramifications.

Although the phenomenon of sacrifice is a central characteristic of most religious traditions, at first glance it seems difficult to fathom it in the context of modernity. Why is it that sacrifice takes on the appearance of an opaque, old-fashioned religious phenomenon, pervaded with strangeness, while at the same time it appears to excite a great topical fascination? In recent years, scholars in cultural anthropology, theology, religious studies, and philosophy have put sacrifice on the agenda again, pointing out the complex and emotionally charged relations between sacrifice and violence, self-sacrifice and autonomy, and religious martyrdom and terrorism. In research and debates, they have attempted to get to the heart of the current fascination with sacrifice. ${ }^{4}$

2 Especially in France, this thesis has found its protagonists, such as Jean-Luc Nancy, Luc Ferry, Giorgio Agamben, and Gianni Vattimo. In a way, the Canadian philosopher Charles Taylor belongs to the same trend.

3 José Casanova, Public Religions in the Modern World (Chicago: The University of Chicago Press, 1994); Charles Taylor, A Secular Age (Cambridge: Harvard University Press, 2007); Jürgen Habermas, “Notes on Post-Secular Society”, New Perspectives Quarterly 25, no. 4 (2008): $17-29$.

4 See Jonneke Bekkenkamp and Yvonne Sherwood, eds, Sanctified Aggression: Legacies of Biblical and Post-Biblical Vocabularies of Violence (London: T \& T Clark International, 2003); Dennis King Keenan, The Question of Sacrifice (Bloomington: Indiana University Press, 2006); Jan N. Bremmer, The Strange World of Human Sacrifice (Leuven: Peeters, 2007); Paul Kahn, Sacred Violence: Torture, Terror and Sovereignty (Ann Arbor, Michigan: University of Michigan Press, 2008); Kathryn McClymond, Beyond Sacred Violence: A Comparative Study of Sacrifice (Baltimore: John Hopkins University Press, 2008); Cleo McNelly Kearns, The Virgin Mary, Monotheism, and Sacrifice (Cambridge: Cambridge University Press, 2008); William T. Cavanaugh, The Myth of Religious Violence (Oxford: Oxford University Press, 2009); Sarah Coakley, Sacrifice Regained: Reconsidering the Rationality of Christian Belief (inaugural lecture as Norris-Hulse Professor of Divinity at the University of Cambridge, October 13, 2009); Stanley Hauerwas, "Sacrificing the Sacrifices of War," in Religion and Politics of Peace and Conflict (eds Linda Hogan and Dylan Lee Lehrke; Princeton: Princeton Theological Monograph, 2009), 83-104; Ingolf U. Dalferth, "Self-sacrifice: from the Act of Violence 
This fascination seems to coincide with an increasing dissemination of the term 'sacrifice' outside the strictly religious domain, it being applied to various phenomena within the public and private spheres that relate sacrifice to, on the one hand, self-destruction and merciless terror, and, on the other hand, to devotion, submission, and self-effacement for the benefit of other people. The violent aspect of sacrifice seems often to be over-emphasized, perhaps due to the highly influential theories of the French philosopher René Girard, on the one hand, and the (over)representation of instances of 'terrorist' martyrdom in the media, on the other. However, a sacrifice can also express gratitude, praise, community spirit, and commitment to the poor, and for many of the faithful the primary meaning of a sacrificial act is best captured in these rather benign dimensions.

The approach to sacrifice guiding this volume is not confined to the dynamics of violence and victimization that often dominates contemporary interests and theories of sacrifice in public debates and academic discussions. We locate our starting point in three central and interlocking aspects of sacrificial performance: sacrifice as a community focused act, sacrifice as a ritually performed act, and sacrifice as an act that is constitutive of (individual or collective) identity. These three angles each point to conjunctures of religiously acknowledged and contemporarily (re)discovered aspects of sacrifice. Combined, these three angles render it possible to address the actual multifacetedness of the phenomenon of sacrifice, and to identify and evaluate its contemporary fascination. These three dimensions make up the three main sections of this book, and in this introduction we clarify the choices and procedures that have engendered its content.

Sacrifice: Changes and Challenges

Sacrifice in Modernity: Community, Ritual, Identity addresses the above introduced conglomerate of questions about the (re)appearance and (re)interpretation of sacrifice in contemporary societies. It represents the outcome of an interdisciplinary and interreligious academic research project examining the current fascination with sacrifice, both in the light of its classic religious

to the Passion of Love," International Journal for Philosophy of Religion 68, no.1-3 (2010), 77-94; Douglas Hedley, Sacrifice Imagined: Violence, Atonement, and the Sacred (New York, London: Continuum, 2011); John Dunnill, Sacrifice and the Body: Biblical Anthropology and Christian Self-Understanding (Farnham: Ashgate, 2013); A. Houtman, M. Poorthuis, J. Schwartz, and Y. Turner eds, The Actuality of Sacrifice, Past and Present (Leiden: Brill, 2015). 
origins and meanings, and through the study of present-day appropriations of sacrifice and their interpretations. Bringing together these two fields of study in an ongoing academic discussion has been one of the project's explicit aims. This joint research project has been organized through a thematic research group (2009-2012) supported by the Netherlands School of Advanced Studies in Theology and Religion (NOSTER). Scholars from various backgrounds and disciplines (religious studies, theology, philosophy, cultural and literary studies) have joined the project, with participants coming from the Netherlands and Flanders. ${ }^{5}$

A central tenet informing the explorations in this volume is the acknowledgment that religious developments have steadily changed the idea and practices of sacrifice, while the extraordinary power and the impact of sacrifice have, in turn, made specific contributions to the development of religious practice and reflection. For instance, not only classical antiquity but also Judaism and Christianity have experienced a decisive turn towards "the discovery of the inner self" during the first centuries of our era. ${ }^{6}$ In the history of sacrificial practices, we simultaneously notice a transition from the literal sacrificing of animals, crops, and libations to more abstract and spiritualized sacrifices in the form of religious study, prayer, charity, and ascetic practices. ${ }^{7}$ Furthermore, the discovery of the inner self has produced new views on corporality and guilt while also changing the function and meaning of ritual as such, and these changes have transformed and 'reinvented' sacrifice. Buddhism, too, shows a spiritual reinterpretation of sacrifice as practiced in Hinduism. ${ }^{8}$ Still, the Vedic sacrifice is seen as the oldest sacrificial practice in human history, and to this day sacrifice constitutes the heart of Hindu religion. ${ }^{9}$

5 See also www.noster.org.

6 Jan Assmann and Guy Stroumsa, eds, Transforming the Inner Self in Ancient Religions (Leiden: Brill, 1999).

7 Guy Stroumsa, La fin du sacrifice: Mutations religieuses de l'antiquité tardive (Paris: Odile Jacob, 2005).

8 James Egge, Sacrifice and Purification: The Meanings of Religious Giving in Theravada Buddhism (PhD diss., The University of Chicago, 1998); Reiko Ohnuma, Head, Eyes, Flesh, and Blood: Giving Away the Body in Indian Buddhist Literature (New York, Chichester: Columbia University Press, 2007).

9 Frits Staal, ed., Agni: The Vedic Ritual of the Fire Altar (Berkeley: Asian Humanities Press, 1983); David M. Knipe, Hinduism: Experiments in the Sacred (San Francisco: Harper, 1991); Selvanayagam Israel, The dynamics of Hindu traditions: The Teape Lectures on Sacrifice, Gita, and Dialogue (Bangalore: Asian Trading Corporation, 1996); Kathryn McClymond, "Death Be Not Proud: Reevaluating the Role of Killing in Sacrifice," International Journal of Hindu Studies 6, no. 3 (2002): 221-242; Timothy Lubin, "Veda on Parade: Revivalist Ritual as Civic Spectacle," Journal of the American Academy of Religion 69, no. 2 (2001): 377-408. 
Sacrifice, as conceptualized and practiced in various religious traditions, has not only experienced major changes, it has also constantly propelled opposition, legitimization, debate, and reflection. Therefore, sacrifice has been at the heart of religious practice as well as of formative religious narratives, imagery and disputes. Famous stories from the Torah, the Qur'an, and the Bible such as Genesis 22, "Abraham's sacrifice", and the passion of Christ - mirror sacrificial practices and comment on them simultaneously. ${ }^{10}$ Theological discussions from the history of religion display the ongoing urge to restate the meaning of sacrifice, evoked by the engraved place it occupies in scripture and liturgy. From time to time new debates emerge which call for reinterpretation of ideas of sacrifice in old and venerated texts. For example, in patristic texts on the biblical figure of Samson we can find a fierce battle over the question of whether Samson, by destroying the temple, his enemies, and himself in one final gesture, was a martyr or someone who merely committed suicide and even whether what he did was an act of religious terrorism. Other issues have retained their relevance to this day, such as whether Christ's death on the cross should be seen as a unique and single sacrifice or whether - as its consequence - a sacrificial attitude is expected and required from a believer as well. This issue continues to divide Roman Catholics and Protestants. Is sacrifice ultimately an achievement and a means to influence the deity, or does it imply submission to the source of life? ${ }^{11}$

Still, it is our conviction that the relevance of sacrifice for understanding modernity's inner tensions, in particular regarding the establishment of community, the practice of rituals and the formation of (individual and collective) identity, goes much further than only these isolated issues. This is why we have brought together various present-day approaches to sacrifice: philosophical perspectives (from the work of, among others, Giorgio Agamben, René Girard,

10 See e.g. Jacob Milgrom, The Binding of Isaac: The Akedah, a Primary Symbol in Jewish Thought and Art (Berkeley, CA: Bibal Press, 1988); Aharon Agus, The Binding of Isaac and Messiah: Law, Martyrdom and Deliverance in Early Rabbinic Religiosity (Albany, New York: State University of New York Press, 1988); Carol Delaney, Abraham on Trial: The Social Legacy of Biblical Myth (Princeton: Princeton University Press, 1998); Daniel Boyarin, Dying for God: Martyrdom and the Making of Christianity and Judaism (Stanford: Stanford University Press, 1999); Jerome I. Gellman, Abraham! Abraham! Kierkegaard and the Hasidim on the Binding of Isaac (Aldershot: Ashgate, 2003); Ed Noort and Eibert Tigchelaar, eds, The Sacrifice of Isaac: The Aqedah (Genesis 22) and its Interpretations (Leiden: Brill, 2002); Edward Kessler, Bound by the Bible:Jews, Christians and the Sacrifice of Isaac (Cambridge: Cambridge University Press, 2005); Lippman Bodoff, The Binding of Isaac, Religious Murders \& Kabbalah: Seeds of Jewish Extremism and Alienation? (Jerusalem, New York: Devora Publishing Company, 2005).

Ivan Strenski, Theology and the First Theory of Sacrifice (Leiden: Brill, 2003). 
Julia Kristeva, Emmanuel Levinas, Jean-Luc Nancy, and Slavoj Žižek); multidisciplinary debates on autonomy and heteronomy; gender-related questions (as put forth by, among others, Carol Delaney, Nancy Jay, Julia Kristeva, Wendy Doniger, Grace Jantzen, Sarah Coakley); ethnological studies; political issues (terrorism, fundamentalism); and theological disputes. Together, these approaches constitute an exciting challenge for interdisciplinary and socially relevant academic research, which has been the aim of this project from the outset.

We have recognized that the term sacrifice refers to a profusion of views and practices, ranging from the actual sacrificing and killing of animals, people, or oneself on behalf of a higher good (a deity, an ideal) to the substitutive and symbolic sacrificing of crops and gifts. Although it is probably impossible to locate one essential characteristic that is shared by all views on sacrifice or common to all sacrificial practices, there are networks of similarities, such as the ritualistic character of some sacrificial practices, the symbolic meanings of others, the way in which the loss implied in sacrifice is legitimized and assessed, or the gift-like character (in either a generous or an economic sense) of sacrifice.

In Beyond Sacred Violence: A Comparative Study of Violence (2008), Kathryn McClymond, a comparative scholar of religion, distinguishes six contemporary approaches to sacrifice: as a dramatized myth; as an exchange or trade; as something people eat (a meal or cuisine); as a ritual without a function, goal, or (symbolic) meaning (structuralism); as a gender-related issue; and as violence. ${ }^{12}$ During the first phase of the project that has led to this book, Kathryn McClymond was invited to elaborate on her approach and to elucidate its value for interdisciplinary and comparative research of religion(s). We are very grateful for her generous and stimulating contributions to the initial debates and presentations of this research project, and we are delighted that she has written the epilogue, in which she discusses the contributions to this volume in light of the comparative study of sacrifice. She rejects the facile association of sacrifice with violence. A community's enjoyment of ritual can also convey an identity of sharing and celebration. Vegetarian sacrifice, flowers, and frankincense, wine libations, prayer and charity - there are many ways to celebrate life without resorting to violence. The threefold division of approaches in this volume, indeed, allows for a much broader exploration of sacrifice, in which the non-violent elements of sacrifice receive as much attention as the violent aspects. 
In order to trace the present-day challenge of sacrifice in its many manifestations, this research project has taken its departure in three exemplary narratives about sacrifice, each stemming from a different religious tradition. In the first stages of the research collaboration, these narratives were presented to all the participants. After the formation of three groups, studying sacrifice from the angle of community, ritual, and identity respectively, the narratives were distributed and taken up in the separate groups' deliberations. Hence, each section opens with a presentation and analysis of one of these key narratives, describing a religious sacrifice in a traditional setting: an African community ritual, a Hindu fire ritual, and the Islamic feast that commemorates Ibrahim's readiness to sacrifice his son. The discussion of the key narratives offers detailed insight into the act of sacrifice as way of establishing community, executing ritual, and marking one's identity. By focusing on the sacrifice as performed or written and exploring their particular context and details, the concerned authors have created a hermeneutical space for discussing the particular complexity of these sacrifices and confronting their often hybrid and enigmatic character. For instance, rather than a simple bargain of do ut des (I give in order that you give), the sacrifice may denote an acute awareness of life as a gift to be enjoyed, and to be shared by those who need it, and consecrated to the divinity who is considered the real owner of it. Hence, sacrifice may denote charity as well as violence, responsibility for the other as well as victimizing the other.

In each section of the book the introduction of the key narrative is followed by the contributions of an interdisciplinary cluster of authors. They were invited to respond to the key narrative and to connect it to a concrete case, narrative, or practice of sacrifice from either their own or a different religious tradition (depending on their own choice). In a series of meetings (both general and per cluster) the authors have discussed the individual contributions. Their topics and approaches will be introduced here by section.

The first section highlights the communal character of sacrifice. The home sacrifice of the Kapsiki, living in Nigeria and Cameroon, is meticulously analysed by the cultural anthropologist Walter van Beek, showing how family ties are renewed and re-established during the celebration of the sacrificial meal. Simultaneously, the implicit exclusion of some family members and 
acquaintances makes clear that communal sacrifices have a complex mechanism of inclusion and exclusion. The remarkable privileged position of the blacksmith only stresses this mechanism further.

Exploring similar and other community establishing dynamics and effects of sacrificial acts, the next contributions in this first section take their inspiration from the refined anthropological research into the Kapsiki home sacrifice. Philosopher of religion Theo de Wit, debating the ideal of offering one's life for a political community in historical and philosophical perspective, demonstrates how soldiers who have died in war are often viewed as martyrs who have sacrificed their lives for their country, thereby strictly demarcating one's own community from that of the other/the enemy. The question arises whether every state needs an enemy in order to create internal coherence and a sense of community.

The highly enigmatic movie The sacrifice, by the famous Russian filmmaker Andrei Tarkovsky, suggests that performing a sacrifice might have implications for the global community. An impending nuclear disaster can be averted if the main character is willing to sacrifice his possessions. Even his son's life is jeopardized in the end. As such, the protagonist seems to be in a similar plight as the patriarch Abraham. Frederiek Depoortere, a theologian from Leuven University, draws parallels to philosophical reflections by Nietzsche and Žižek. Whether the obligation to sacrifice is either a phantasmagoric delusion or a genuine obligation towards the godhead remains ambiguous.

The German poet Friedrich Hölderlin offers another artistic expression of sacrifice, in which the poet seems to allude to himself as the glorified hero or the victim - which brings up the relationship between the individual and the community. Humanistic scholar Rebecca Prevoo and philosophical anthropologist Joachim Duyndam analyse the different versions of the tragedy of the Greek philosopher Empedocles, who threw himself in the Mount Etna volcano. His self-destruction could be explained as a reaction to the people's contempt, in which case Empedocles took it upon himself to assume the role of a scapegoat. Even then, the sacrifice and the community maintain an intrinsic relationship.

The expression "sacrifice of the self" may point to violence and a denial of autonomy, but the researcher of humanistic studies Saskia van Goelst Meijer points out that freedom fighters, like Gandhi and Martin Luther King, use precisely this expression to describe what they see as a prerequisite for nonviolence. However, what they point to is a very different understanding of (self-)sacrifice, one that actually leads to autonomy and empowerment. In any case, an easy dismissal of the concept of "sacrifice of the self" as no longer being acceptable to modern people is apparently not a viable option. Noting 
the non-violent connotation of sacrifice, her views align with those of Kathryn McClymond, who we have already mentioned.

\section{Section II: Sacrifice and Ritual}

The second section, on sacrifice and ritual, opens with a narrative from Vedic Hinduism. Myths about the origin of sacrifices are strongly intertwined with rituals, which revives the old debate about the priority of myth over rite, or vice-versa. Again, there is a shifting away from the facile association of sacrifice with violence. At first sight, these highly intricate and age-old rituals seem to escape logic as well as explanation. Indologist Albertina Nugteren emphasizes their refined creative connotations: creation itself is re-enacted in these rituals. As such, the ritual of sacrifice transgresses the thin demarcation line between the rational and the irrational, between the functional and the sacred, the linear and the cyclic, as well as between human and animal existence.

Early Christianity had its own perspective on sacrifice. The rituals of sacrifice were transformed into the Eucharist rather than abolished, the historian of Christian theology Gerard Rouwhorst argues. Although the bloody sacrifices were considered a pagan remnant or a Jewish practice that should not be continued, the sacrificial terminology and the reminiscences of the Temple remained in force. Even the practice of bringing food to be distributed to the poor to the Church, thereby transforming sacrifice into charity, can be documented in early Christianity and has remained relevant to this day.

The unexpected relevance of sacrifice to the position of religion in modern society came up with the debate in the Netherlands about the ritual slaughter of animals in Judaism and Islam. Voices to stop this practice altogether received unexpected support. Historian Bart Wallet demonstrates how this debate comes up time and again, sometimes initiated by extreme right-wing parties, at other times by environmental activists - not to mention the medical profession. The supposedly cruel sacrificial ritual fuels the image of religion as an outdated phenomenon within Western society.

In the work of the Japanese Catholic novelist Shūsaku Endō, the theme of the relationship between humans and animals plays a considerable role as well. Theologian Sigrid Coenradie, exploring the theme of sacrificial substitution in Endō's fictional works, describes a ritual process of Stellvertretung, the substitution of the human life by an animal, not unlike the story of Abraham and the ram. Coenradie's comparative reading of sacrificial substitution in Endō's narratives brings to light several interesting differences with regard to Abraham's ritual focus and its moral consequences: in Gen. 22, the relationship 
between Abraham and God seems to take priority over the human relationships of Abraham and his wife Sarah, his son Isaac, and his friend Eliezer, whereas the relationship of the main character in Endō's stories to the unknown giver of the animal substitute seems to improve the relationship to his family.

Young girls can tell you all about it: the extremely popular vampire stories of the Twilight Saga, encompassing four bulky volumes and several films. Theologian and ethicist Grietje Dresen shows the highly erotic nature of the central notion of ritually shedding blood in the saga, paradoxically combined with a culture of sexual abstinence. Although the young - mostly female readers recognize the fictional character of the saga, its strongly 'romanticized' vampire stories offer them the possibility to confront and appropriate the highly ambivalent ritual meanings of female blood that in many cultures constitute the greatest taboo.

The so-called apocryphal story of the biblical heroine Judith has fascinated painters and libretto writers alike. The height of her heroic action is undoubtedly the display of the head of Holofernes, who was decapitated by this beautiful woman while lying on his bed. The story ends, however, with Judith and the Israelites bringing the spoils to the Temple in Jerusalem to be dedicated to God. Biblical studies scholar Anne-Mareike Wetter discovered numerous rituals and sacrificial acts in the biblical text. She draws a picture of Judith not as the violent femme fatale, which may be a modern projection of male fantasies, but as the embodiment of religious female creativity, via trajectories different from the traditional male ritual performance.

\section{Section III: Sacrifice and Identity}

Central to the third section, on sacrifice and identity, is the famous story, common to the three monotheistic religions, of the patriarch Abraham being asked by God to sacrifice his beloved son. Abraham/Ibrahim proves his identity as a firm believer and thus becomes the paragon of faith. Islamic theologian Abdelilah Ljamai acquaints us with this story as told in the Qur'an. The wealth of commentaries makes clear that for Islam, when it comes to the question of the identity of the son, Ishmael is not the only option, as is often thought. The story remains a prime example of the act of sacrifice because of the three crucial elements of the enhancement of the identity of Abraham/Ibrahim by showing his faith, the conscious consent of the victim (the beloved son), and the replacement of the human victim with an animal. The redemption of the human victim by an animal sacrifice is celebrated as a major religious holiday in Islam. 
A phenomenological description of sacrifice in human relations makes clear that victimizing the other or victimizing oneself in order to influence the other can easily happen within families. As such, the redemptive value of sacrifice should be sought for in a therapeutic context, theologian and ethicist Mariéle Wulf argues. The free act of sacrificing oneself for the other should be distinguished from being branded as the scapegoat.

Gertrud von le Fort's Die letzte am Schafott (1931, translated as The Song at the Scaffold) contains a severe criticism of imposing sacrifice upon someone else, theologian Marcel Poorthuis argues. The story pictures Carmelite sisters resisting the confiscation of their convent during the French revolution and the condemnation to death of sixteen sisters. The highest and most selfassured authority among the Carmelite nuns flees from the scaffold, whereas the young Sister Blanche, full of fear from her childhood onwards, joins her fellow nuns out of free will on their way to martyrdom. By recognizing one's fear of death and by embracing life in all its beauty, can sacrifice have the meaning of enhancing one's identity, Gertrud von Le Fort seems to profess.

Historian Marjet Derks tells the history of a spiritual Catholic movement of young women, the Grail movement. Initially, in the 1920s, sacrifice was considered the essence of this spiritual community. The founder, a charismatic priest, even advocated sacrificial and ascetic exercises especially for these women, because of their supposedly greater ability to bear pain. After the 196os, however, the sacrificial language gave way to self-affirmation and autonomy. At times the initial predilection for sacrifice has even become flatly denied.

It is no coincidence that the ethics of care comes across the issue of selfsacrifice so often. The easy solution, to replace self-sacrifice by autonomy and self-determination, does not satisfy ethicist Inge van Nistelrooij. She explores the ambiguous dimensions of caring for the other, both in its possibilities and its limitations. The tragic element in the awareness that more can always be done should not be ignored, but sustained.

Perhaps the most famous of the literary protagonists featured in this book is Harry Potter. Theologian Sigrid Coenradie sees striking similarities between his story and the biblical story of Abraham and his son, as well as between Harry's and Jesus' suffering and death. There is an element of vocation in Harry's life, coupled with the fact that he never kills but, instead, is prepared to give his life out of love. Just like the son in the Qur'anic story, Harry acts out of free will.

The story of Abraham being commanded to sacrifice his son constitutes a formidable challenge to modernity because of its seemingly heteronomous character. Although the story has a happy ending and militates against human sacrifice, the story does not fail to shock a modern predilection for autonomy. The many Jewish commentaries on the story of Abraham and Isaac introduce 
an altogether new figure, Satan, by which the story receives a multilayered tapestry of ethical deliberations. Abraham's readiness to sacrifice his son is traditionally considered to be proof of his identity as a believer in God. The post-Biblical re-readings strongly challenge this picture. Satan's arguments seem to coincide with those brought forward by modern thought. Let us face it: he is the one who tempts Abraham not to kill his son. Theologian Elliot Lyons describes how in a strong dialectics of good and evil the Jewish Midrash portrays Abraham as almost the embodiment of evil and as being out of his wits, whereas Satan appears as the wise adviser. Even the offering of a lamb belongs to the latter's recommendations, but apparently Abraham has to endure the test until the very end before this solution becomes relevant. It is clear that this way of re-interpreting the biblical story avoids a monolithic message of sacrifice, allowing all sorts of objections and new perspectives instead.

Ethics, responsibility, scapegoating, the individual and the community between autonomy and heteronomy, compassion, grace, creativity in the postmodern ritual, the relationship between humans and animals, which has become a highly relevant issue in modernity - these are only some of the themes that have proved relevant while pondering over the ongoing fascination with sacrifice. It is the axiom of this volume that substantive insight into modernity's fascinations and paradoxes regarding community, ritual, and identity could be gained from a sacrificial perspective, or, at least, a perspective informed by the sacrificial practices, vicissitudes, and reflections of religious communities and traditions. 